\title{
STONE DETERIORATION CHARACTERIZATION FOR ITS CONSERVATION
}

\author{
A. Elena Charola \\ Research Scientist, Museum Conservation Institute, Smithsonian Institution, Washington, DC \\ charolaa@si.edu
}

\begin{abstract}
The conservation of stone is fundamental for the preservation of our architectural and monumental heritage. Although stone is reputed as one of the most resistant materials, there are many factors that contribute towards its deterioration. This paper aims to summarize the main deterioration factors, such as air pollution, the presence of soluble salts, and biocolonization. A brief discussion of these factors serves as the basis to introduce the importance of a correct diagnosis regarding the origin of the observed deterioration. Only then, can the most appropriate solution be found to address the problem.
\end{abstract}

Keywords: stone nature, deterioration, conservation

Resumo: CARACTERIZAÇÃO DA DETERIORAÇÃO DAS PEDRAS PARA A SUA CONSERVAÇÃO. A conservação da pedra é fundamental para a preservação do nosso património arquitectónico e monumental. Embora seja um dos materiais mais resistentes, deve-se considerar que existem muitos factores que podem contribuir para a sua deterioração. O presente trabalho sintetiza os principais factores de deterioração, tais como a poluição atmosférica, a presença de sais solúveis e a biocolonização. Uma breve resenha destes factores serve de base para salientar a importância de fazer o diagnóstico correcto da origem da deterioração observada. Só então se pode encontrar a solução mais adequada para resolver o problema.

Palavras Chave: tipo de pedra, deterioração, conservação.

\section{INTRODUCTION}

Stone conservation is fundamental for the preservation of our architectural and monumental heritage. Stone has always been considered as one of the most resistant building materials, but this is not always the case, since there are many varieties, some more resistant than others, depending on their originand formation. Consequently, each building, each monument is really unique, and to preserve it requires first a thorough condition survey, based on a careful observation and analysis, so as to be able to correctly identify its deterioration problem, carry out a value analysis, so that an appropriate solution can be found.

This paper aims to present a brief introduction to the most common deterioration factors so as to identify and evaluate the most important points that should be taken into account when carrying out a condition survey of the building or monument. It is not always possible to carry out all the analyses that would be desirable to confirm the observed problems. Therefore, it is critical that in a first evaluation, the type of stone and the main deterioration problems be identified so as to reduce to a minimum the number of required analyses. A correct diagnostic is fundamental for determining the best conservation method to be used, while also taking also into account the overall objective of the intervention.

\section{DETERIORATION FACTORS}

Stone is susceptible to deterioration by various agents, the most important ones are air pollution, the presence of soluble salts, and biocolonization, apart from freeze-thaw issues as found in colder regions. All these deterioration mechanims have one common factor: the presence of water (CHAROLA and WENDLER, 2015, p. 55). Many studies have been undertaken to elucidate these mechanisms and to understand how each individual factor acts by itself, or in conjunction with others. While science has made great advances in this area, the practical application of this knowledge has lagged behind. Many conservation interventions failed because the actual problem was not correctly diagnosed. A correct diagnosis of the problem is required to identify its origin so as to allow finding the best solution to it. Only then, can an appropriate conservation intervention be designed.

\subsection{Air Pollution}

Air pollution became very important in countries where the industrial revolution brought with it the great technological advances. The subsequent pollution problems have been well described for the case of London in the works of Charles Dickens (1812-1870). The black crusts that formed on the surfaces of the buildings and monuments are the physical evidence of the problem. The first attempt to eliminate the musing a grit (i.e., sand) blasting technique, was carried out in Paris around 1955. Unfortunately, most buildings were constructed from a relatively soft local limestone and the amount of damage induced was only realized later. Around 1960, the origin of air pollution was recognized but appropriate measures to control it were only implemented in subsequent decades (BABOIAN, 1986; ROSVALL and ALEBY, 1988).

To understand the air pollution problem it is important to differentiate dry deposition, i.e., when it is not raining, from wet deposition, the so-called acid rain. Dry deposition occurs in proximity to industrial and/or urban areas and generally is far more important than wet deposition. Gaseous pollutants, such as sulfur oxides $\left(\mathrm{SO}_{2}\right.$ and $\left.\mathrm{SO}_{3}\right)$, 
generally referred to as $\left(\mathrm{SO}_{\mathrm{x}}\right)$, originate from various industries; while nitrogen oxides ( $\mathrm{NO}$ y $\mathrm{NO}_{2}$ ), simplified to $\left(\mathrm{NO}_{\mathrm{x}}\right)$, are emitted by vehicular traffic. These, together with air-borne particles and aerosols are deposited on the surface of the buildings forming a layer. Their concentration in the air, molecular diffusion and atmospheric turbulence will determine the amount deposited, as well as the nature and roughness of the stone in question. A critical factor is the time-of-wetness of the stone, i.e., how much humidity does the stone surface store from moisture condensation or after a rain event, since water will facilitate the reaction between the pollutants and the material.

On the other hand, wet deposition, during rain or fog, is less important in urban areas. But it can be critical for rural areas. The reason for this is that rain is normally acid ( $\mathrm{pH} \sim 5.6)$ from the dissolution of carbon dioxide and subsequent formation of carbonic acid. Pollutants transported by rain originate at long ranges and because their concentration during the initial rain fall is high, the acidity can reach low $\mathrm{pH}$ values $(\mathrm{pH} \sim 3)$, however, as the rain continues, the pollutants are washed out, and the rain returns to its normal value.

An important point for the deterioration process are the hydrodynamics of the rainfall on the monuments, as originally identified by GUIDOBALDI (1981), and this is also related with the three characteristic deterioration patterns that develop on limestone and marble depending on how water wets them (CAMUFFO, 1990): white areas, where the surface is eroded; black areas, with no run-off but where condensation or percolation occurs; and, gray areas, with no run-off, condensation or percolation. The latter only collect a surface layer of dust but they are not chemically corroded.

Black crusts are the result of the reaction of sulfur oxides with the calcite, calcium carbonate $\left(\mathrm{CaCO}_{3}\right)$, present in calcareous substrates, such as limestone, marble, calcareous sandstones and lime mortars, following a typical acid attack in the presence of water. The resulting formation of gypsum $\left(\mathrm{CaSO}_{4} .2 \mathrm{H}_{2} \mathrm{O}\right)$ incorporates into it solid particles, such as fly ash, carbon, dust, etc., turning the deposit black. Much has been published on this subject, such as BRIMBLECOMBE (2014); CAMUFFO (2013); SABBIONI (2003); CHAROLA and WARE (2002); CHAROLA (1998), and CAMUFFO et al.(1982).

\subsection{Soluble salts}

Soluble salts, such as sodium chloride $(\mathrm{NaCl})$, sodium sulfate $\left(\mathrm{Na}_{2} \mathrm{SO}_{4}\right)$, and sodium or potassium nitrate $\left(\mathrm{NaNO}_{3}, \mathrm{KNO}_{3}\right)$, can be considered the factor that in general induces most damage to stone and that can, in some instances, induce the fastest deterioration. Soluble salts are ubiquitous, for example, $\mathrm{NaCl}$ can be found in suspension in the atmosphere in marine environment, while $\mathrm{Na}_{2} \mathrm{SO}_{4}$ is found in desert areas, and $\mathrm{KNO}_{3}$ is found in bat guano deposits. Since they are highly soluble they easily dissolve in water, even in deserts there is sufficient water for at least a partly dissolution, and in solution they can migrate and enter by capillarity the pore system of stones. Once in the stone, water will tend to evaporate at the surface of the stone, leaving the salts behind forming efflorescences and subflorescences. Repetition of this cycle results in the slow accumulation of salts within the porous material. Another point to be considered is that the solubility of less soluble salts, such as gypsum, and even calcite-approximately 100 times less soluble than gypsum-, increases significantly when in presence of salts that do not have a common ion with them, such as $\mathrm{NaCl}$ or $\mathrm{KCl}$.

To illustrate the point, we can consider a stone monument and its base in contact with the ground. If the soil around it is moist, from rain or groundwater, any soluble salts present will dissolve in it and the solution will rise by capillary action and ascent through the base to the monument. The different salts that are present will migrate to various heights as a function of their solubility as described by Andreas Arnold (1982) and crystallize in various habits depending on the environmental conditions during water evaporation (ARNOLD and ZEHNDER, 1991).

The issue of salt deterioration is particularly complex, as not only does the crystallization of salts, either as anhydrate or a hydrated salt induce stresses during this process, but changes in relative humidity will induce further recrystallizations from hydrate to anhydrate, or vice-versa. The reason for this process is the hygroscopicity of soluble salts, which can be defined as the adsorption of water vapor, i.e., moisture, from the air. While most materials are hygrospic, highly soluble salts are particularly so, adsorbing moisture to a degree that turns them deliquescent, i.e., they dissolve in their own adsorbed moisture. This results from the fact that the water vapor pressure over a salt solution is lower than over pure water and will decrease with increasing salt concentration. The minimum is reached when a saturated solution is formed. This point is called the deliquescent relative humidity (DRH). Each soluble salt has a specific DRH, for $\mathrm{NaCl}$ this is $75 \% \mathrm{RH}$ at $20 \circ \mathrm{C}$, if the ambient humidity increases above $75 \% \mathrm{RH}$, the $\mathrm{NaCl}$ starts absorbing moisture and eventually deliquesces. If the ambient $\mathrm{RH}$ decreases, the salt in solution will start crystallizing out. But if this salt is in solution with $\mathrm{NaNO}_{3}$, whose DRH is also about $75 \% \mathrm{RH}$, there is no longer a single $\mathrm{DRH}$ value but a range of them, between $\sim 75 \%$ and $\sim 67 \% \mathrm{RH}$, depending on the 
concentration of each of the salt in the mixture (STEIGER, 2005).

Damp walls in buildings may very well be the result of hygroscopicity of the soluble salts present in them. In general, the first diagnostic in these cases is rising damp, but in general it is forgotten that the maximum that rising damp will reach is about $1 \mathrm{~m}$ height, the general case being between 15 to $25 \mathrm{~cm}$. Any moisture found above 1 meter height can be attributed to the hygroscopicity of salts that accumulated over time in the walls of the building (CHAROLA and BLÄUER, 2015; LUBELLI et al., 2006).

Another point that has to be considered is that if the stone in question contains clays, particularly expansive ones (from the smectite or montmorillonite group), these will adsorb moisture and expand, thus inducing yet another deterioration mechanism, i.e., expansion-contraction. This mechanism that is mostly reversible when only water is present, but if salts are also present, the cycles are no longer reversible and the expansion increases significantly with each new cycle (SNETHLAGE and WENDLER, 1997; LUBELLI et al. 2006).

From the vast literature about soluble salts, the following are useful for obtaining a general perspective on the topic: SIMON and DRDÁCKÝ (2006); DOEHNE (2002); CHAROLA (2000); GOUDIE y VILES (1997);BEHLEN et al. (1997); PÜHRINGER (1983).

\subsection{Biocolonization}

Biocolonization is yet another deterioration factor that impairs stone materials, however, it is not as critical as those induced by soluble salts or air pollution, but the increasing climate changes may well turn it into a more serious issue in the future. Biocolonization is the growth of microorganisms and plants on the surface of stone. These can induce soiling, discoloration, patinas, and fouling, as well as some chemical attack, especially on limestones and marble. Biological growth on stone is dependent on both climatic and microclimatic conditions, while the bioreceptivity of the substrate depends upon its nature, i.e., mineralogical composition, petrographic properties, surface roughness and porosity; while the presence of water is fundamental (MILLER et al., 2006; CANEVA et al., 2004; WARSCHEID and BRAAMS, 2000).

A frequent question is how does this biocolonization occur. Microorganisms, spores, pollen and other biological material are also present in the air. Their deposition of surfaces, will follow a similar pattern as that of air pollution particles. Once deposited, micro-organisms tend to form a biofilm to protect them from then environment (GORBUSHINA, 2007; KEMMLING et al., 2004).To protect themselves, microorganisms secrete extracellular polysaccharide substances (EPS) that will form a coating, the biofilm. This protective layer retains moisture so that environmental changes of humidity are mitigated. But not all organisms will be on the surface, some of them mayactually penetrate into the stone, especially those with translucent minerals, such as quartz or calcite, that allow light to reach the interior pass. These endolithic microorganisms, may also dissolve the carbonate stone and create microcavities (DePRIEST and CHAROLA, 2007). Endolithic biocolonization, especially on white limestone, may turn it visually grey. Once a biofilm is established, the colonization of the stone surface may be followed by that of higher order organisms. The microorganisms in the biofilms, bacteria, fungi and algae, may then progress to allow the development of lichens, followed by mosses, liverworts and ferns. Subsequently, grasses, bushes and trees may develop; at this point, mechanical damage by root development can induce significant damage. A simplistic description of this process can be found in CEDROLA and CHAROLA (2009).

While biodeterioration at the incipient stage is not very damaging, once higher plants develop, as is the case in many archaeological sites in tropical areas, the damage induced may be significant. The soiling and staining of initial biocolonization may be an aesthetic issue for monuments and elimination of this growth may be necessary; this appears a fairly easy task but it has to be understood that biological growth will return and may develop resistance to the biocide(s) applied, or more aggressive organisms may develop. Elimination of higher plants should be carried as soon as ferns and grasses grow. In archaeological sites, where trees have already developed, their eradication has to be considered within the context of the site and its value. The following publications address the various issues discussed in more detail: CANEVA et al., (1991); CAMERON et al. (1997); KUMAR and KUMAR (1999); CIFERRI et al. (2000); KOESTLER et al. (2003); CHAROLA et al. (2011).

\section{DISCUSSION AND CONCLUSIONS}

The deterioration topics briefly discussed previously serve as an illustration of the complexity of deterioration mechanisms and the fact that in many cases, they may be misdiagnosed. For example, a grey coloration on a white limestone may be the result of a "grey" area from air pollution, or the result of an endolithic biocolonization. To differentiate them, it is critical to observe the location of these areas and whether rain washes 
over them or not. Therefore, a close observation of the building is fundamental for its evaluation.

When considering a conservation intervention on a monument or a historic building, it is critical to identify the deterioration mechanism that may be affecting it, in other words, the diagnosis of the problem. But equally important is to consider its "value", historic, artistic, etc. This requires that as much background and historical information be obtained as possible. Likewise, documentation of the "present" condition of the monument, i.e., the condition survey, is essential. Both of these, the historical information and the condition survey, are the first step required for developing a conservation strategy. The subsequent step is the diagnosis of the problem, to identify the deterioration mechanism so as to determine the most appropriate conservation approach to be taken and considering that in most cases there may be several ways to solve the problem. In conjunction with the diagnosis, the objective of the conservation intervention needs to be defined, especially in the case of buildings that will continue to be used as such. Therefore a consensus has to be reached between these sometimes contradicting values. For this purpose, what is called a "value analyses" should be carried out, between all parties involved in the process: historians, architects, scientists from the different disciplines, geologist, biologists, chemists, physicists, conservators and the "owner" of the object in question. The value analysis also considers the costs and benefits of all the possible solutions, and based on these, the most appropriate can be chosen.

As human beings we have limitations: in many cases, especially if we are familiar with a building, as for example maintenance personnel, we "see" the building, but we do not "look" at it unless a major change occurs. So looking at the problem, and observing it at different times and conditions, will help to obtain a correct diagnosis. In most cases, however, problems are easily solved if addressed as soon as they appear: a gutter that needs cleaning, a leaking pipe. These minor problems need to be dealt with immediately to avoid the increased damage that will develop over time and then be far more difficult and expensive to address. The most critical point is finding the balance between problempossible solution-maintenance of the monument or building in question.

\section{REFERENCES}

AMADORI, M. L., LAZZARINI,L.,MASSA, S. II deterioramento da sodio cloruro di rocce compattee porose aVenezia.In: ZEZZA, F.1st International Symposiumon the Conservationof Monuments in the Mediterranean Basin. Brescia: Grafo, 1990.p. 83-89.

ARNOLD, A. Rising damp and saline minerals. In: GAURI, K. L.,GWINN, J. A., 4th International Congress on the
Deterioration and Preservation of Stone Objects, Louisville, KY: University of Louisville, 1982, p.11-28.

ARNOLD, A., ZEHNDER, K. Monitoring Wall Paintings Affectedby Soluble Salts. In: CATHER, S. The Conservation of Wall PaintingsProceedings of a Symposiumorganized by the Courtauld Institute of Artand the Getty Conservation Institute. Los Angeles, CA: The Getty Conservation Institute, 1991, p. 103-135.

BABOIAN, R. Materials Degradation Caused by Acid Rain. Volume 318. Washington, DC: American Chemical Society, 1986, 447 p.

BEHLEN, A., M. STEIGER, and W. DANNECKER. 1997.Quantification of the salt input by wet and dry depositionon a vertical masonry. In: A. Moropoulou, 4th InternationalSymposium on the Conservation of Monumentsin theMediterranean Basin. Athens: Technical Chamber of Greece, 1997, p. 237-46.

BRIMBLECOMBE, P. Environment and architectural stone. In SIEGESMUND, S., SNETHLAGE, R. Stone in Architecture. Properties, Durability. Berlin-Heidelberg: Springer Verlag, 2014, p. 317-347.

CAMERON, S., Urquhart, D., Wakefield, R., Young, M. Biological Growths on Sandstone Buildings.Control and Treatment. Technical Advice Note 10. Edinburgh: Historic Scotland, 1997, $40 \mathrm{p}$.

CAMUFFO, D. Microclimate for Cultural Heritage. Waltham, MA; San Diego,CA: Elsevier, 2013, 557 p.

CAMUFFO, D. Acid precipitation research in Italy. In: BRESSER, A H., SALOMONS, W., Acidic Precipitation. Vol. 5. International Overview and Assessment. New York: Springer Verlag, 1990, p. 229-265.

CAMUFFO, D., DEL MONTE, M., SABBIONI, C. Origin and growth mechanisms of the sulfated crusts on urban limestone. Water, Air and Soil Pollution, Vol. 19 (1982) p. 351-359.

CANEVA, G., DI STEFANO, D., GIAMPAOLO, C, RICCI, S. Stone cavity and porosity as a limiting factor for biological colonization. In: KWIATKOWSKI, D., LÖVENDAHL, R. $10^{\text {th }}$ International Congress on Deterioration and Conservation of Stone. Vol. 1.Stockholm: ICOMOS-Sweden, p. 227-232.

CANEVA, G., NUGARI, M. P., SALVADORI, O. Biology in the Conservation of Works of Art. Roma: ICCROM, $182 \mathrm{p}$.

CEDROLA, M.,CHAROLA, A. E. Biodeterioro de materiales porosos inorgánicos. In: CHAROLA, A. E., MAGADÁN, M. L. Manual Básico de Conservación para las Misiones JesuíticasGuaranies. New York: World Monuments Fund and UNESCO, p. 52-62. https://www.wmf.org/library?keywords=Misiones \%20Jesuiticas\%20Guaranies

CHAROLA, A. E. Salts in the deterioration of porous materials. Journal of the American Institute for Conservation, Vol. 39(2000) p. 327-343.http://ncptt.nps.gov/blog/2000-25/

CHAROLA, A. E. Review of the Literature on the Topic of Acidic Deposition on Stone.The National Center for Preservation Technology and Training, 1998. p.1-85. http://ncptt.nps.gov/blog/review-of-the-literature-on-thetopic-of-acidic-deposition-on-stone-1998-09/

CHAROLA, A. E., BLÄUER, C. Salts in masonry: an overview of the problem. Restoration of Buildings and Monuments, Vol. 21[4-6] (2015) p. 119-135

CHAROLA, A. E., WARE, R. Acid depostion and the deterioration of stone: a brief review of a broad topic. In: SIEGESMUND, S., WEISS, T., VOLLBRECHT, A. Natural Stone, Weathering Phenomena, Conservation Strategies and Case Studies. London, Geological Society Special Publication No.205, 2002, p.393-406. 
CHAROLA, A. E., WENDLER, E. An overview of the water-porous buildingmaterials interactions. Restoration of Buildings and Monuments, Vol. 21[2-3] (2015) p. 55-65.

CHAROLA, A. E., McNAMARA, C., KOESTLER, R. J. Biocolonization of Stone: Control and Preventive Methods. Smithsonian Contributions to Museum Conservation No.2. Washington, DC: SI Scholarly Press, 2011, 115 p.http://opensi.si.edu/ index.php/smithsonian/catalog/book/67

CIFERRI, O., TIANO, P., MASTROMEI, G. Of Microbes and Art. The Role of Microbial Communities in the Degradation and Protection of Cultural Heritage. New York: Kluwer Academic/Plenum Publishers, 2000, 250 p.

DePRIEST, P.T., CHAROLA, A. E. Biological olonization and "ink strokes" on buildings. In: SLEDGE, J. CHAROLA. A. E., Paula T. DePRIEST, P. T, Koestler, R. J.Conservation of the Exterior of the National Museum of the American Indian Building. Smithsonian Contributions to Museum Conservation No.6. Washington, DC: SI Scholarly Press, 2007 (in press) http://opensi.si.edu/index.php/smithsonian/catalog/series/S $\mathrm{CMC}$

DOEHNE, E. Salt weathering: a selective review. In: SIEGESMUND, S., WEISS, T., VOLLBRECHT, A. Natural Stone, Weathering Phenomena, Conservation Strategies and Case Studies. London, Geological Society Special Publication No.205, 2002, p. 51-64.

GORBUSHINA, A. A. Life on the rocks. Environmental Microbiology, Vol. 9[7] (2007) p. 1613-1631.

GUIDOBALDI, F. Acid rain and corrosion of marble. An experimental approach. In: ROSSI MANARESI, R. The Conservation of Stone II. Bologna: Centro per la Conservazione delle Sculture all'Aperto, 1981, p. 483-497.

KEMMLING, A., KÄMPER, M., FLIES, C.,SCHIEWECK, O., HOPPERT, M. Biofilms and extracellular matriceson geomaterials, Environmental Geology, Vol. 46 (2004) p. 429-435.

KOESTLER, R. J., KOESTLER, V. H., CHAROLA, A. E., NIETOFERNANDEZ, F. E. Art, Biology, and Conservation: Biodeterioration of Works of Art. New York: The Metropolitan Museum of Art, 2003, 572 p.

KUMAR, R., KUMAR, A. V. Biodeterioration of Stone in Tropical Environments: An Overview. Los Angeles, CA: The Getty Conservation Institute, 1999, $86 \mathrm{p}$.

LUBELLI, B. Sodium Chloride Damage to Porous Building Materials. Ph.D. Thesis. Delft: Technical University, 2006, p. 1-168.

LUBELLI, B., VAN HEES, R. P. J., HUININK, H. P., Groot, C. J. W.P. Irreversible dilation of $\mathrm{NaCl}$ contaminated lime-cement mortar due tocrystallization cycles. Cement and Concrete Research,Vol. 36 (2006) p. 678-687.

MILLER, A., DIONISIO, A., MACEDO, M. F. Primary bioreceptivity: a comparative study of different Portuguese lithotypes. International Biodeterioration and Biodegradation, Vol. 57 (2006) p. 136-142.

PÜHRINGER, J. Salt Disintegration. Salt migration and degradation by salt - a hypothesis. D15:1983. Stockholm: Swedish Council for Building Research, 1983, p. 1-159.

ROSVALL, J., ALEBY, S. Air Pollution and Conservation. Safeguarding our Architectural Heritage. Amsterdam-New York: Elsevier, 1988, p. 1-438.

SABBIONI, C. Mechanisms of air pollution damage to stone. In: BRIMBLECOMBE, P. The Effects of Air Pollution on the Built Environment. London: Imperial College Press, 2003, p. 63106.

SIMON, S. DRDÁCKÝ, M. Problems of Salts in MasonrySALTEXPERT. European Research on Cultural Heritage. State of the Art Studies.Vol.5. Prague: Institute of Theoretical and Applied Mechanics, Academy of Sciences of the Czech Republic, 2006, pp. 1-368.

SNETHLAGE, R., WENDLER, E. Moisture cycles and sandstone degradation. In: BAER, N. S. y SNETHLAGE, R. Saving our Architectural Heritage. The Conservation of Historic Stone Structures. Dahlem Workshop Reports. Chichester y New York: J. Wiley and Sons. 1997, p. 7-24.

STEIGER, M. Salts in porous materials: thermodynamics of phase transitions, modeling and preventive conservation. Restoration of Buildings and Monuments, Vol. 11[6] (2005) p. 419-432.

WARSCHEID, T., BRAAMS, J., 2000. Biodeterioration of Stone: A Review. International Biodeterioration and Biodegradation, Vol. 46 (2000), p. 343-368.

Contribuição ao

10. Simpósio Brasileiro de Caracterização e Conservação da Pedra 14 a 16 de dezembro de 2016, Congonhas - MG

Nota:

É de responsabilidade da comissão editorial do Simpósio a revisão gramatical, ortográfica, de citações e referências bibliográficas. As normas de submissão podem se diferenciar das desta revista. 